\title{
Religion, civil society and conflict: What is it that religion does for and to society?
}

\begin{abstract}
Author:
Jaco Beyers ${ }^{1}$

Affiliation:

${ }^{1}$ Department of Science of Religion and Missiology,

University of Pretoria,

South Africa

Note:

This article was presented as a paper at the 32nd ASRSA

(Association for the Study of Religion in Southern Africa)

Congress held on 26-27

August 2010 at the University

of South Africa, Pretoria.

\section{Correspondence to:}

Jaco Beyers

Email:

jbeyers@telkomsa.net

Postal address:

PO Box 14125, Lyttelton

0140, South Africa

Dates:

Received: 27 Aug. 2010

Accepted: 16 Dec. 2010

Published: 01 Aug. 2011

How to cite this article: Beyers, J., 2011, 'Religion, civil society and conflict:

What is it that religion does for and to society?', HTS Teologiese Studies/ Theological Studies 67(3), Art. \#949, 8 pages. doi: 10.4102/hts.v67i3.949
\end{abstract}

(C) 2011. The Authors. Licensee: AOSIS OpenJournals. This work is licensed under the Creative Commons Attribution License.
Human consciousness instinctively tries to make sense of reality. Different human interpretations of reality lead to a world consisting of multiple realities. Conflict occurs when differing realities (worldviews) encounter one another. Worldviews are socially created and determine human behaviour and, as such, most often find expression in religion. The discussion of conflict and the role of religion in civil society take place within the discourse of the sociology of religion. Religion is socially determined. Peter Berger's insight into the sociology of religion therefore plays an important role in establishing the relationship between religion and civil society as one that takes on different forms. Thus, a clear definition of both civil society and religion was needed to understand the nature of these relationships. The role of religion in civil society with regard to the presence of conflict in society was further investigated in this article. The conditions under which conflict in society occurs were discussed, as were the conditions for tolerance in society, for religion ultimately becomes the provider of moral discernment when conflict occurs in civil society.

\section{Introduction}

The debate on the nature of civil society, and even on the nature of religion, has been going on for centuries. Recently, there seems to be a new interest in the concept of civil society. Religion has always been under discussion, but when it comes to the relationship between civil society and religion, we return to an old debate. This relationship takes on new forms depending on the context and by adding a third element, namely conflict, to the equation, the relationship does indeed become complex.

This article intends to investigate the role of religion when it comes to the presence of conflict in society. As will be pointed out, this conflict can relate to society itself being in conflict with governing bodies, or relate to groups (even different religions) within society which stand in conflict with one another or with government. Within such groups there can even be conflict present. The question is: does religion play a role in such situations and if it does, what should the role of religion be?

\section{Sociology of religion}

The debate on the role of religion and civil society takes place within the discourse of sociology. Seligman (1992:2) acknowledges that the roots of the debate on civil society do lie partly in social philosophy. Religion is socially determined, that is, religion influences and is influenced by society.

The debate on the position of religion and civil society is ongoing. At times, this debate is seen as a discussion between two independent entities opposed to one another and, at others, this debate acknowledges the coherency of the two. The former stance can be labelled 'religion and society'. In the latter stance, the statement 'religion in society' would be more appropriate.

Religion and society are closely connected. Although differentiation between the two is possible, complete separation seems impossible. It seems that the discussion of the hierarchy of the two leads to certain perceptions. Is it society that gives rise to religion or is it rather religion that gives rise to society? Or is it more correct to formulate the inseparability by saying society is religion and religion is society. Nevertheless, it is clear that the fate of religion and society is intertwined. Religion is something essentially social (Dürkheim, cited in Robertson 1969:53). The one cannot exist without the other. Religion gives birth to all that is essential in society (Dürkheim, cited in Robertson 1969:48).

Human beings create the world within which they exist. Peter Berger (1967:4) explains this 'world-constructive' ability further: human beings create society, which entails all manmade 
elements (material and nonmaterial culture, including society and religion) (Berger 1967:7). Religion is part of the result of the construction of society. Only within society can religion continue to exist (Berger 1967:7). But by the process of what Berger calls 'objectivation' (1967:9), the product of humanity's intent takes on a life of its own and stands independent of its creator. 'In other words, the humanly produced world attains the character of objective reality' (Berger 1967:9). Natural order becomes cultivated or civilised order.

This free independent existence of the product of humanity's creative ability, namely society and religion, continues further to determine human behaviour through what Berger (1967:17) calls a process of 'internalization'. In other words, the product of humanity's constructive ability, after attaining a life of its own, starts exerting control over its maker. The once 'object' that human beings created, starts acting as a subject (Berger 1967:17).

Therefore society, and for that matter religion, is seen as a product of humanity's world-constructive ability and simultaneously becomes something sui generis (Berger 1967:4) that can now govern humanity's actions and thoughts. Society becomes a human-constructed institution. As institution, society is simultaneously a 'product of human activity' which '... has attained the status of objective reality' (Berger 1967:11). The understanding of society as institution provides the background for the concept of civil society. The inseparable bond between religion and society is therefore an important element to consider in this discussion. This close bond is emphasised by Dürkheim: '.. the idea of society is the soul of religion' (cited in Robertson 1969:48).

On this inter-relatedness of society and religion, Schmidt (1988:307) states that religion does something for and to society. As to the function of religion within society, Schmidt (1988:306) states that religion is seen as the conservator of social order and systems of meaning. Religion as a system of meaning guides human behaviour and determines interactions in society (Schmidt 1988:306). The guidance of society by religion is seen as the basis for the discussion on the role of religion in society when it comes to conflict.

\section{Definitions of civil society and religion \\ What is civil society?}

\section{An historical overview of the development of the concept}

Cohen and Arato (1995:84) identify the first mention of the concept of civil society in Aristotle. Aristotle's apparent understanding of this concept, as well as the subsequent Roman understanding, came to refer to the structure of the city-state (polis) as a society which functions as an ethicalpolitical community, with the characteristics of freedom and equality under the rule of law (Cohen \& Arato 1995:84). The community shared in a set of norms and values which determined political as well as everyday life. Religion played a role in providing the ethical guidance for behaviour.
In Aristotle's construct there was no distinction between state and society. The social system was all-inclusive, containing all groupings, thus also allowing no distinction between society and communion (koinonia) (Cohen \& Arato 1995:84). Koinonia came to represent all forms of association, thus acknowledging the existence of a 'plurality of forms of interaction, association, and group life' (Cohen \& Arato 1995:85). Religion was therefore part of the free association in community; however, this plurality of forms functioned as a single organised body, as a community consisting of societies (Cohen \& Arato 1995:85). It can be surmised that the ancient polis was a system where the people governed the people.

The medieval city-state was the next to see itself as the continuation of the ancient understanding of the polis (Cohen \& Arato 1995:85), but this was a misconstruction as medieval city-states never reached the level of autonomy that Aristotle envisaged for the polis. According to Cohen and Arato (1995:86), the coming of absolutism (or the authoritarian state) marked the division between the traditional and modern meanings of civil society. A duality came into being, with all political power now in the hands of the ruler and a depoliticised society (Cohen \& Arato 1995:86). However, this did not create an impotent society. Society could now flourish through the reorganisation of different associations (i.e. religiously, economically and politically). This development during the Enlightenment is regarded as the starting point for the understanding of the modern concept of civil society (Cohen \& Arato 1995:87).

During the Enlightenment, Hobbes suggested an alternative concept of state, which was that the state be identified with civil society as it can only be sovereign power that provides the bond between individuals (Cohen \& Arato 1995:87). This seems to be a return to the ancient Greek concept of no division between state and society. Locke, however, suggested the continuation of the identity of political and civil society, but one which sets them apart from the state (Cohen \& Arato 1995:87); despite acknowledging the close connection between society and state, Locke differentiates between the two.

The next influential thinker regarding civil society was Montesquieu, who suggested a differentiation between public or political law (regulating relations between those who govern and those who are governed) and civil law (regulating relations between members of society). By this division, Montesquieu attempted to empower society politically, setting it up as a system against absolute rule, referred to as anti-absolutism (Cohen \& Arato 1995:88, 89). During the Enlightenment the understanding was that society was a body opposed to the state. Members of society were seen as autonomous individuals and society was exclusively the source of legitimate authority (Cohen \& Arato 1995:89). The state, individuals and society itself seemed as if they were subject to the authority of society itself.

Hegel presented a different approach to understanding civil society. His thinking on civil society led to a theory of a differentiated and highly complex social order (Cohen \& Arato 1995:91). Hegel gave birth to a concept incorporating 
a descriptive and prescriptive function. For Hegel, the ideal was that the ancient republican idea (derived from Aristotle's thoughts) was supported dually by ethical life and public freedom (Cohen \& Arato 1995:91). An understanding of morality (ethics) played an important role in Hegel's understanding of civil society. Society is reminded continually by the ethical call of what ought to be as opposed to as things are. Hegel's concept consisted of several polarities: ensuring the separation between state and civil society whilst allowing these bodies to remain interdependent on each other. Society is seen as a world of alienation and, simultaneously, is searching for social integration (Cohen \& Arato 1995:92). Hegel indeed presents a complex understanding of civil society as one that consists of many seemingly opposing ideas.

Seligman (1992:ix) points out how, during the Scottish Enlightenment, new arguments for the continuation of the concept of civil society were provided. However, Karl Marx's critique on civil society led to a period in history when the whole idea of an autonomous society fell in disrepute. Marx interpreted civil society as consisting of 'isolated and aggressive individuals' united by economic interests (Femia 2001:135). Marx understood civil society as the replacement of collective units by the autonomous individual, causing civil society to lose its political character (Femia 2001:135). Individuals operate in society now no longer motivated by a common good, but by selfish interest. According to Marx, civil society was therefore supporting materialism (Femia 2001:136); man is abusing others and simultaneously allows himself to be abused in order to reach financial gain. Civil society alienated man from the community and from himself and others (Femia 2001:136). Yet Marx's understanding of civil society was reduced and limited to his economic interpretation of society and with such a negative evaluation of civil society, the concept soon fell out of favour. Berger (2005:11) attests to this by commenting that up until the 1960s, the term 'civil society' was rarely, if ever, used. Nevertheless, the concept found new meaning in the 1970s in the Polish political struggle between workers and state (Seligman 1992:ix). The political awakening of Eastern Europe provided new impetus for renewed interest in the role civil society plays in governing itself (Seligman 1992:1, 4).

Historically, civil society came to mean different things to different people and Herbert (2003) discusses three stages of development of the concept of civil society. During the first stage, the concept of civil society was broad and idealistic (Herbert 2003:73); civil society came to refer to all institutions next to the state. The second level of development of the concept was introduced by Karl Marx's critique on the supportive function of civil society for capitalism as an oppressive system and simultaneously forwarding selfish private interest (cited in Herbert 2003:73). Although the concept of civil society fell out of favour, it was seen in the light of a continuous power struggle between civil society and the state, where the latter is seen in a negative light and civil society comes to present all that is virtuous (Herbert 2003:73).

A third, emergent level of understanding of the concept of civil society was established by a much more nuanced and precise understanding of civil society. Although the apparent understanding of civil society (as in the first stage) re-emerged under new social conditions in the 1980s, a new refined concept was posited during this time (Herbert 2003:75). This new, third stage was not as general as the first stage and not as narrow and simplistic as the second; rather, it saw an interconnectedness between civil society and the public sphere (Herbert 2003:75). According to Seligman (1992:3), the concept of civil society rests on two apparent contradicting ideas: the equality and freedom of the individual and the autonomy of the community of individuals. This leads to the understanding of civil society as maintaining constant tension between the private and the public sphere (Seligman 1992:5). Civil society enables private opinion to drift through to the public sphere. Recent developments in the understanding of civil society emphasise the idealistic character of civil society (Keane 1998:6). For a deeper discussion on this, see the discussion on the normative aspect of civil society below.

\section{Defining civil society}

Although by now a commonly acknowledged concept, the idea of civil society is still multilayered. There are different ways of understanding civil society, as judged by the different forms civil society take in different cultural contexts. Kaviraj and Khilnani $(2001: 2,3)$ suggest a differentiation between a Western, a Southern and even a Third World understanding of the concept of civil society. Civil society comes to mean different things in different traditions (Edwards 2004:vii; Seligman 1992:ix) and, as such, there cannot be one single universal understanding of civil society. Tester $(1992: 5,13)$ points out the subjective and existentialistic character of researching civil society when he suggests that 'civil society is best understood as a confrontation with the very possibility of society itself ...' Civil society therefore seems to confront society with its own existence, questioning the relevance and functioning of existing structures. The answers to that questioning may themselves be diverse.

Why then the current urgency to discuss the concept of civil society? Is it because it has become a dying ember that needs to be rekindled, or has it become a raging fire that needs to be understood to be controlled? Edwards (2004:ix) reckons that no solution to social, economic or political problems in the 21st century is possible without civil society as a vehicle for change. Seligman (1992:15) suggests that the reason for the new debate on civil society is due to a crisis in social order, a point to which Wuthnow (1996:11) attests by pointing out how leaders worldwide are concerned about the breakdown of intermediary institutions in civil society, such as the family, the church and neighbourhood associations. The concern about the breakdown of the moral values governing society (Wuthnow 1996:11) makes the re-opening of the debate more urgent. The same situation that restarted the debate on civil society in the 17th and 18 th centuries, namely the breakdown of the paradigms governing social life, is today, once again, the reason for taking up the debate (Seligman 1992:15).

Modern (and postmodern) society has become averse to oppressive rule from the top; society wants to participate in 
governing itself. Several structures are employed to assist in this governing function, including voluntary associations, churches and communities (Seligman 1992:2) and even nongovernmental organisations (Edwards 2004:2). Religious affiliations are part of these associations. These groups that spontaneously form within civil society are based on interest (Seligman 1992:162) and not on grounds of national (cultural) coherency. As Wuthnow (1996:7) puts it, civil society is the sphere where a balance between individual and collective values and community participation is maintained.

Following Berger's analysis (1967:17) of the process of socialformation, civil society can best be described as the 'coming of age' of society. This implies an autonomy that emphasises the ability of society to govern itself. No oppressive or destructive body (state) or ideology would be tolerated to govern over a society that now lives a civilised lifestyle. Decisions and actions are made and initiated by society. Society operates independently from the institution of state and interdependently with all associations within society, of which religious association is one. Berger (2005:12) therefore defines civil society as the institutions which arise outside of the official hierarchies of church and state. These institutions, of which religious institutions are part, arise as voluntary associations (Berger 2005:12). Habermas gives direction to Cohen and Arato's understanding of civil society as 'the institutionalization of the life world embedded in basic rights' (cited in Herbert 2003:93).

\section{Theory of civil society}

\section{Three theories for understanding civil society}

Edwards $(1998,2004)$ identifies three theories which can be used to understand the role that civil society plays within our larger societal structure. These are as follows:

The analytical position: This corresponds with the descriptive position of analysing life in civil society. According to this understanding, civil society is part of a society set apart from state and financial institutions. It is formed with the purpose of advancing the common interests of the community. It also facilitates collective actions in the community. According to this understanding, civil society is seen to contain all associations and networks between the family and the state (Edwards 2004:vii)

Similarly, Tester (1992:13) defines civil society as a category to explain one's social condition, socially as well as historically. The need to define one's own social condition grows from a position of loss or deprivation of confidence in the natural order. The natural order of society is understood as a hierarchical social order willed by God. The majority of the definitions of civil society probably fall under the analytical position.

The normative position: According to this understanding, civil society comes to mean a type of society that is driven by a different way of existing in the world, or what Edwards (1998:viii) calls a different rationality, identified as 'civil'. Edwards's suggestion corresponds to the ideal-type that Keane (1998:6) proposes: the position where civil society sets a type as an ideal to be realised. Keane defines civil society in terms of ideal-types, following the sociological interpretations of Max Weber. Civil society, according to Keane (1998:6), presents normative types of institutions that non-violently stand in tension with one another and with the state. The state determines the borders of the institutions' activities. The purpose of ideal-types is to set a benchmark against which reality can be measured. Ideal-types shape the interpretation of reality (Keane 1998:6). Yet even though the associations in civil society are bound by the ideal character, this does not imply homogeneity. Due to the diversity of forms there is not one common goal (Edwards 2004:viii). This may be identified as one of the roots of conflict in society.

Seligman (1992:x) adds another dimension to the normative perspective on civil society. Civil society resembles the ethical ideal of the social order where the interests of the individual are weighed up against what is best for the community and a balance is established between the two. The ideal proposed can then never serve only the interests of either the individual or the community, but both are aligned towards the ideal.

Civil society seems to have the purpose of challenging existing structures and activities and testing whether these are ideal for the community. Civil society therefore encourages society to change and adapt to changing environments. Such change can be interpreted by some as relinquishing past traditions or paradigms and therefore poses a threat to existence, which consequently leads to conflict.

The public sphere: With this category, Edwards (1998:viii) identifies those activities in society where open, public debate on social issues of common interest takes place. These public discussions are an expression of 'active citizenship' which enables the functioning of the 'public sphere' (Edwards 1998:viii). This understanding of the relationship between the public and private sphere characterises the current understanding of civil society (cf. Seligman 1992:5).

Hann (cited in Herbert 2003:86) proposes that civil society not be defined negatively as if it stands against state and government, but rather defined positively. This would mean civil society operates within the context of ideas and activities which induce cooperation and trust in society.

\section{What is religion?}

The origin and nature of religion is sociological. Religion is something that happens in a community amongst and between people. Berger (1967:25) defines religion concisely as the 'human enterprise by which a sacred cosmos is established'. Humankind creates a universe with sacred meaning through a process of sacralisation. The way in which religion is expressed, however, is culturally determined. The result is a religious pluralistic environment in which society consists of various religions stemming from different cultural backgrounds.

Sundermeier (1999:27) defines religion as the communal answer of people when encountering the transcendental, and which is expressed in ethics and rituals. This expression has 
implications for the function of religion in civil society. We will come back to the ethical contribution of religion when discussing the role religion plays in civil society regarding conflict situations below.

By acknowledging the communality of the response to the encounter with the transcendental, Sundermeier (1999) agrees to the sociological character of religion. However, Sundermeier differs from Berger by indicating that humankind does not create the focus of religious attention; the transcendental exists independently of humanity. According to Berger, humankind creates the religious focal point by ascribing sacred character to elements. The realm of the sacred transcends, and simultaneously includes, human beings (Berger 1967:26).

This created sphere becomes institutionalised through processes which Berger calls externalising and objectivation (Berger 1967:9, 27). As man ascribes (sacred) meaning to reality, a new universe is constructed. After a while this construct is objectified and gets a life of its own; the manmade construct becomes an institution. The institution has rules, regulations, fixed structures and is in need of maintenance. The institution exists independently of humanity and starts governing human behaviour and decisions. Religion in its instituted form is part of the voluntary associations which make up civil society.

As to the characteristics of religion as institution, Berger $(2005: 14,15)$ identifies the elements of religion as being intermediate and voluntarily. Although part of civil society, religion as institution does not exclusively belong to the public sphere or the structures of state or economy (Berger 2005:14). Religion is sui generis. Furthermore, the association with religion is voluntary. Individuals have the liberty to choose the religion to which they want to belong (Berger 2005:14) and civil society offers a vast diversity of religions from which individuals can choose. Berger (2005:15) compares the religious pluralistic community to a market situation where religions compete for the attention of the individual.

The relationship between religion and civil society takes on different forms. At times, the relationship between religion and civil society takes on an aversive nature (religion against culture), where two autonomous entities try to destroy each other. This relationship can also be described as being subversive when religion and civil society try to subdue each other (religion above culture). Religion and culture see each other as a potential threat. This power play is identified by Foucault (cited in Herbert 2003:73), who sees civil society as being determined by a power struggle; civil society is a complex network of power relations. Habermas (cited in Herbert 2003:63) also attests to this when he understands civil society as consisting of associations formed spontaneously with the purpose of ventilating social reaction to social problems to the public sphere. The two key concepts here are power (what Habermas calls 'reaction') and groupings (called 'networks' by Foucault and 'associations' by Habermas). This power struggle can lead to conflict.

Yet, at times, the nature of the relationship between religion and civil society is more supportive (religion in culture).
Religion promotes and carries culture(s) represented in society and, as such, is a mirror image of society. This occurs mostly when there is only one religion present in a community.

The mere origin and nature of religion creates the possibility of conflict. Whether religion is the creation of a sacred world (according to Berger) or the means through which humanity can become aware of an already existing transcendental world (according to Sundermeier), religion creates different interpretations of reality. These differences, if not kept in check, create potentially explosive situations.

\section{Conflict and the role of religion in civil society}

Now that the ground has been set for an understanding of the relationship between civil society and religion, the central questions remains: what is the effect of conflict on this interaction?

\section{Conflict theory}

A brief description of what is meant by conflict is necessary here. Religion does not only have a positive function and effect on society; it can, at times, be the perpetrator who causes disharmony, pain and guilt. Conflict is not necessarily the absence of peace and harmony, but rather a process of understanding and determining the status of parties in relation to one another. The most probable understanding of conflict would be to understand conflict as the result of differences. The cause of conflict can also lie within the infringement on rights and status. Conflict can also be handled in different styles; however, the styles should not be confused with the element of conflict itself. Aggression, revolt, violence and armed struggle are just as much styles of handling conflict as are lethargy, passivity, isolation and silence. Conflict regarding religion in civil society can take on different forms.

\section{Conflict between religion and civil society}

According to this perspective religion becomes the enemy of civil society. Marx described the sedative and misdirecting effect of religion (Johnstone 2004:115), referring to the manipulation by religion of society to gain advantage or serve self interest. Foucault's concept of power, as cited in Herbert (2003:73), also applies here. Religion and civil society are in conflict because they are engaged in a struggle to gain power in order to dictate community life.

Religion itself contributes to the potential for conflict in society. Berger (2005:15) indicates how religion can create conflict in and between societies by having a divisive influence on communities. He therefore concludes that religion should not be seen as a powerful force for tolerance and peace. In some communities religion and its leaders can vie for power in order to regulate individual behaviour in society and the end result is that civil society becomes enslaved by religion. The utopian future is then created by religion and not civil society. A struggle or conflict might thus ensue to throw the 
burden of religion from the shoulders of society, for a free society has the freedom to decide on association.

A second case of conflict might be where religion is not the perpetrator or instigator of conflict, but takes on the role either of liberator, freedom fighter or judge. Religion takes up the struggle fighting alongside the wronged in order to restore justice and freedom. In this case, religion can either be on the side of society in conflict with the state, or be on one side of associations in society in conflict.

\section{Conflict amongst different associations in civil society}

Conflict arises mainly as the result of pluralism of civil society (Keane 2003:14). Society consists of a vast differentiation of people from different religious convictions and different means of making a living, all trying to live together in one society. It is exactly this diversity that creates the potential for conflict (Keane 2003:14).

Society can be compared to a market situation regarding the availability of different religions. Religions are then in conflict with one another in order to increase the number of adherents (cf. Berger 2005:15). There are limited resources available to society and religions compete for the attention and support of members of society. This competition is a form of conflict between religions, a phenomenon which Johnstone (2004:120) refers to as 'interreligious conflict'. Religions compete for power and the resulting conflict stems from an understanding of the validity and truth claim of religions. An exclusivist and particularistic attitude expressed by religions endorses conflict (Johnstone 2004:123). By proving other religions as untrue, ridiculous or invalid a religion can gain more power in society. Establishing a clear theology of religions is therefore necessary to maintain peace and harmony amongst religions; however, this falls outside the scope of this article.

\section{Conflict between religion and state}

There are many examples in human history of religion taking up a social cause and defending a position against a political structure. Religions' reaction to social injustice might be supportive, opposing or neutral (Johnstone 2004:131). These differing positions may again lead to interreligious conflict. State structures may also contribute to social injustices. Poverty, oppression, discrimination and manipulation of society are all instances where religious groups feel obliged to partake in a struggle to restore justice. When religion is ignorant of conflict it is just as guilty of being the perpetrator maintaining injustice.

Conflict between state and society would also entail conflict between state and specific associations within civil society. This would resemble a vertical line of conflict as state and associations stand in a hierarchical position towards one another. But conflict can also occur amongst societies in community when groups of free association in society stand in conflict with one another. This can be illustrated as a horizontal line of conflict as associations would then stand as equals beside one another.

\section{Conflict within religious groups}

Johnstone (2004:123) identified this phenomenon is as 'intrareligious conflict'. This form of conflict takes place within a religion where there might be differences either pertaining to different interpretations of doctrine and practices, or cultural influences from society creating division amongst adherents of one religion. Many such conflict situations are caused by differing perspectives. Johnstone (2004:130) identifies two main groups that cause friction within a religion: liberals and conservatives. Often, liberal members of a religion oppose the more conservative adherents within their faith. Liberalism and conservatism are two perspectives related to societal worldviews.

\section{Worldviews}

Reality is socially constructed (Berger 1967:15). Reality is formed by way of interpreting knowledge (what people know) and is not necessarily based on ideas (what people assume); the latter leads to an ideological interpretation and presentation of reality. Conflict occurs when differing realities encounter one another. Worldviews are also socially created and determine human behaviour (Berger 1967:15), often finding expression in religion. However, when the worldviews of two groups differ, this difference creates tension within society. Indeed, in a conflict situation it is clashing worldviews and not necessarily opposing religious convictions that cause tension. Society therefore needs to be aware of differing worldviews.

With new worldviews continually arising, there is prone to be differences in acceptance of a new worldview. Throughout history, worldviews have marked human attempts to discover and establish a foothold on reality (Keane 2003:1). Currently, Keane (2003:1) identifies the rising of a new worldview: that of global civil society. As in the past, the coming of a new worldview will again lead to unavoidable conflict when opposing worldviews encounter one another, but also when followers of different worldviews find it difficult to make the change from one understanding of reality to another.

When religion does not allow the coming of age of society, conflict is oppressed and differences are ignored. Where religion allows society to come of age, conflict will occur and differences are not oppressed but rather encouraged. Diversity and plurality of ideas and beliefs are necessary to challenge society to find new ways of existence. Religion therefore plays a crucial role in managing conflict.

\section{Role of religion in civil society to manage conflict The role of religion in civil society}

What is it that religion does for and to society, as Schmidt (1988:306) would like us to ask? One answer, according to Herbert $(2003: 4,5)$, is to divide the role religion has played in civil society over the past three decades into two distinct areas: 
- providing education and/or welfare functions in societies where the state is unable or unwilling to provide these services

- speaking or acting out against political oppression or the undermining of political institutions by the state.

The conclusion Herbert (2003:5) reaches regarding the role of religion in civil society when it comes to the process of democratisation, is that religion can have a dual effect: it can either bring about social division or social integration. Berger (2005:15) attests to this in principle by answering the question of whether religion can contribute to civility. His conclusion is an ambiguous 'yes and no', depending on the situation. As to the political role of religion in civil society, Wuthnow (1996:3) indicates how religious communities played a role in the rebuilding and maintenance of voluntary bases of self-government. Yet, in the end, Berger (2005:15) states that religion probably can only cause harm to civility, as religion becomes the dividing factor between societies. Religion divides, or positively put, religion is not a powerful force for tolerance and peace. This notion leads Herbert (2003:73) to conclude that religion can indeed be a threat to civil society. Wuthnow (1996:3) illustrates this dividing force of religion by referring to the efforts of several religions to recapture their earlier position of authority and prominence in societies and thus actually generate conflict. However, it is unclear whether Berger here refers only to the second level of religion's role in civil society (i.e. speaking out against political oppression) as identified by Herbert. Can religion truly only do harm to civil society? Perhaps this is true on the political front, as Berger indicates.

\section{Religion as provider of morals}

A third important aspect should be added to these two roles of religion in civil society identified by Herbert: religion provides the moral structure to civil society. This is, however, not something new. Hegel already indicated the importance of ethics as a base for social life (Cohen \& Arato 1995:91). Paeth (2008:129) attests to this by pointing out religion's involvement in the process of moral formation within the community. Civil society does indeed need a prescriptive function as to how society ought to behave. Humankind needs moral values (Berger 1967:147). Religion becomes relevant, according to Berger, because of the fact that religion becomes the provider of such morals in private life.

As to the proper values needed in society, Juergensmeyer (2005:6) indicates that religion promotes certain values, namely honesty, justice, fair play, tolerance and respect. These values are necessary for the maintenance of society (Juergensmeyer 2005:6, 8). The role ascribed to religion regarding conflict in civil society would then be to provide the values for a moral community in conflict (Juergensmeyer 2005:8).

To assign any other function to religion, would be to make religion the judge, or measure against which truth and justice is measured. The moment religion becomes the peacemaker or referee in a conflict situation within society it would require a choosing of sides. Who was the aggressor, instigator or perpetrator who acted unjust, untrue or unlawful, and who has become the victim, sufferer, oppressed or harmed? In such instances decisions would be subjective, leading to never-ending debates on issues such as which religion becomes the measure, who has the truth, what is lawful, what is just? Religion would thus end up causing the harm and social division to which Berger (2005:15) referred. Religion should therefore maintain an objective position, or as Berger (2005:14) calls it, an 'intermediate' position, standing somewhere between the public sphere and the structures of state and economy. From this uncompromising position, religion can provide a moral structure to society.

However, the problem deepens when the religious plurality of society is taken into account. The question then becomes: which religion should have its set of morals accepted as the norm? Juergensmeyer (2005:5) provides a solution when he discusses the phenomenon of globalisation of religion. He suggests that the collective values of the globalised religion would suffice (2005:6). The worldwide moral community will agree on the biggest common values amongst religions.

The problem of plurality can further be solved by employing the contribution of religions as the providers of the moral for morals, as religions then agree on a method on how to determine applicable norms for society. Religion itself becomes the appeal on society to transcend its existence and strife for a better way of life - cf. Keane's (1998:6) suggestion of the ideal-type. Religion encourages ethical behaviour in society because it reminds society of the objective existence of a higher power (the sacred cosmos) guarding over mankind, judging human behaviour. In this sense, religion's place in civil society is best described by Seligman (1992):

The idea of civil society thus embodies for many an ethical ideal of the social order, one that, if not overcomes, at least harmonizes, the conflicting demands of individual interest and social good.

(Seligman 1992:x)

Religion therefore sets the benchmark against which civil society measures its own efforts to overcome conflict.

\section{A civil or uncivil society?}

Although now considered by some to be an archaic term, 'uncivil', according to Keane (1998:115), comes to denote the opposite of civil behaviour. Conflict leading to violence and uncontrolled aggression would denote uncivility. It is required of civil society to behave in such an accommodating way that no member of society feels threatened or oppressed. Civility is a basic requirement in society and, as Keane (1998:114) points out, especially under conditions of conflict. Civility, then, does not denote the absence of conflict but merely a civil way of managing conflict.

A civil person would constitute an individual who sets the civil society as priority superseding their own interests (Keane 1998:114). This is based on common reciprocal respect in society. Reciprocal respect is pointed out by Keane (1998:129) to be one of the key principles organising civil society. The result of reciprocal respect in community is to acknowledge the need of the poor and deprived, for even the poor and needy deserve respect. This respect is expressed in acts of 
social assistance, through which society takes responsibility for the welfare of those in need. The lack of such assistance might lead to a division in society demarcated between those who have and those who have not. Every member of society must be held accountable for their actions either to promote or reject cohesion in society.

\section{Conclusion}

A discussion on religion and civil society falls under the discourse of sociology. Civil society plays a role in social cohesion (Paeth 2008:128) and therefore should not be understood as being composed of several autonomous elements linked together. It is also not true that civil society functions as one homogenous organ for which the internal parts cannot be differentiated. Civil society is more effectively understood by its ability to create an environment for association and participation of various associations (Paeth 2008:128).

Civil society consists of many forms of institutions with which individuals voluntarily associate (Paeth 2008:131, 142). Religion is one of the free associations existing in society, operating autonomously as an intermediate category rather than choosing sides between associations in society or even between state and civil society. The function of religion is utopian in nature; through it, society is reminded of a better way of existence through the presentation of an ideal-type. Should conflict occur in society, either between rival associations or between state and civil society, religion provides the moral integrity according to which the conflict is resolved. Religion provides a moral formation in order for individuals to participate in social life in such a way that religious teachings are reflected (Paeth 2008:129).

Religion also promotes civility. Part of civil life is taking care of the needy in society and religious associations play an important role in this regard (Herbert 2003:4, 5; Paeth 2008:129). The degrees to which religious associations participate in delivering social services in communities reflect the moral standards of society, as well as their level of awareness of social responsibility. In this regard, there are numerous examples of religious groups providing social relief to people in need: ranging from providing clean drinking water to counselling HIV-positive members of society. These humanitarian actions are initiated by a variety of religions, not only by one or two.

Civility is not the absence of conflict but the proper, civilised manner in which differences are resolved. Differences in society occur due to different interpretations of reality. The matrix for understanding reality is a worldview. Different worldviews can coexist, yet individuals following different worldviews can end up with vastly differing interpretations of reality (systems of meaning) and consequently end up in a conflict situation. The very nature of civil society is pluralistic (Paeth 2008:130) therefore creating a vast array of possibilities of ideas. Religion provides the morals for how these differences are treated. In a religious pluralistic community, religions present their worldviews to others in a respectful and tolerant manner. Together adherents of different religions carry a collective responsibility to maintain an orderly society. Paeth (2008:147) suggests that religions have the responsibility to retract on their claim to uniqueness and intolerance in order to maintain harmony in society, whilst Berger (1967:27-28) identified how religion provides the sphere where individuals can feel part of a larger meaning system.

The primary moral principles necessary for resolving differences are reciprocal respect, responsibility and accountability. Respect is a basic requirement for individuals living in close proximity and can be defined as acknowledging the differences and rights of others to have an opinion of their own. Humans also have a responsibility for the wellbeing of fellow human beings and this is especially true in civil society, where the well-being of the community supersedes the individual interests. With responsibility goes accountability. Every member of society must be held accountable to the way in which fellow members of society are treated and how the environment of society is managed.

With these remarks a new (postmodern) slogan for society might be born. Based on the slogan that emerged during the French Revolution, which also came to mark a new beginning in civil society, the slogan 'liberté, égalité, and fraterné', can be replaced by the call of religion on civil society for: Respect, Responsibility and Accountability.

\section{References}

Berger, P., 1967, The sacred canopy: Elements of a sociological theory of religion, Anchor Books, New York.

Berger, P., 2005, 'Religion and global civil society', in M. Juergensmeyer (ed.), Religion in global civil society, pp. 11-22, Oxford University Press, Oxford. doi:10.1093/ac prof:oso/9780195188356.003.0001

Cohen, J.L. \& Arato, A., 1995, Civil society and political theory, The MIT Press, Cambridge.

Edwards, M., 2004, Civil society, Polity Press, Cambridge.

Femia, J., 2001, 'Civil society and the marxist tradition', in S. Kaviraj \& S. Khilnani (eds.), Civil society: History and possibilities, pp. 131-146, Cambridge University Press, Cambridge.

Herbert, D., 2003, Religion and civil society: Rethinking public religion in the contemporary world, Ashgate Publishing Ltd, Hampshire.

Johnstone, R.L., 2004, Religion in society: A sociology of religion, Pearson Education, Upper Saddle River.

Juergensmeyer, M., 2005, Religion in global civil society, Oxford University Press, Oxford. doi:10.1093/acprof:oso/9780195188356.001.0001

Kaviraj, S. \& Khilnani, S. (eds.) 2001, Civil society: History and possibilities, Cambridge University Press, Cambridge.

Keane, J., 1998, Civil society: Old images, new visions, Stanford University Press, Stanford.

Keane, J., 2003, Global civil society?, Cambridge University Press, Cambridge. doi:10.1017/СBO9780511615023

Paeth, S.R., 2008, Exodus church and civil society: Public theology and social theory in the work of Jurgen Moltmann, Ashgate Publishing Ltd, Hampshire.

Robertson, R., 1969, Sociology of religion: Selected readings, Penguin Books, New York.

Schmidt, R., 1988, Exploring religion, 2nd edn., Wadsworth Publishing Company, Belmont.

Seligman, A.B., 1992, The idea of civil society, Princeton University Press, Princeton.

Sundermeier, T., 1999, Was ist Religion? Religionswissenschaft im theologischen Kontext, Gütersloher Verlagshaus, Gütersloh.

Tester, K., 1992, Civil society, Routledge, London.

Wuthnow, R., 1996, Christianity and civil society, Trinity Press International, Philadelphia. 